\title{
Juridical Analysis of The Obligations of The Indonesian Medical Disciplinary Board in Resolving Complaints of Patient Losses
}

\author{
Istiana Sari ${ }^{1}$, Megawati Barthos ${ }^{2}$ \\ \{istianasari10@gmail.com ${ }^{1}$, megawati_barthos@borobudur.ac.id ${ }^{2}$ \} \\ Universitas Borobudur, Jakarta, Indonesia ${ }^{1,2}$
}

\begin{abstract}
In Law No.29 of 2004 concerning Medical Practice in Indonesia, Indonesian Medical Disciplinary Board (IMDB) is assigned as an autonomous organization approved to decide mistakes in the utilization of clinical disciplines did by specialists and dental specialists. The obligations of IMDB needs to be initiated in order to optimize the tasks of the IMDB and resolving complaints about patient losses. This IMDB obligation need to be initiated because the absence of regulation regarding IMDB obligation causes the independence of the IMDB become a public problem that is widely questioned. This in turn will potentially make IMDB able to act arbitrarily and if it were a super body. In addition, IMDB is often giddy and acts beyond its authority because IMDB is not exposed to the spirit of a balance of rights and obligations. To examine and analyze how the IMDB obligations are set for the settlement of complaints about patient losses in the context of optimizing the duties and functions of the IMDB and how the legal structure of the IMDB's decisions in the context of enforcing disciplinary sanctions of the medical profession on doctors and dentists who violate professional disciplines, research has been carried out using normative juridical methods, analytical descriptive specifications and prescriptive analytical, statutory approach method, limited empirical and conceptual. The regulation of the IMDB's obligations for the settlement of complaints about patient losses has not been comprehensively regulated in the existing regulatory instruments. The legitimate situation of the Indonesian Medical Disciplinary Board's choice with regards to implementing disciplinary approvals on the clinical calling on specialists and dental specialists has not been obviously and unambiguously depicted comparable to lawful.
\end{abstract}

Keywords: Obligation; Professional discipline; Doctor; Indonesian Medical Disciplinary Board (IMDB)

\section{Introduction}

The Indonesian Medical Disciplinary Board (hereinafter referred to as IMDB) is an autonomous institution from the Indonesian Medical Council (hereinafter referred to as IMC) which was established based on the Law on Medical Practice and functions as a supervisor for 
the provision of health services with the aim of upholding the discipline of the profession of doctors and dentists in Indonesia.

As indicated by Article 66 of Law Number 29 of 2004 concerning Medical Practices in Indonesia and the elaboration of Article 3 of the Indonesian Medical Council Regulation No.3 of 2011 concerning the Organization and Work Procedure of the Indonesian Medical Disciplinary Board at the Provincial Level, IMDB has the obligation to get grievances, look at and choose associated cases infringement with the expert discipline of specialists and dental specialists. Article 66 of Law Number 29 of 2004 concerning Medical Practices in Indonesia passage (1) expresses that: "Everyone who knows or whose interests have been hurt by the activities of a specialist or dental specialist in completing clinical practice can submit a composed question to the IMDB." Unfortunately, the guideline in regards to IMDB's commitments in settling patient misfortune grumblings has not been managed in different laws and guidelines.

One of the objectives of the Unitary State of the Republic of Indonesia as communicated in area IV of the introduction to the 1945 Constitution of the Republic of Indonesia is to propel public government help. The boundaries for the advancement of general government assistance incorporate advancing government assistance in the wellbeing area for residents. The requirement for a sound life is a fundamental need. Acknowledgment of the right to medical care as a common liberty has been perceived internationally and is expressed in article 25 of the 1948 Universal Declaration of Human Rights. With the order of the right to wellbeing administrations as a component of common liberties, every nation is obliged to ensure the satisfaction of this ideal for every one of its residents. Acknowledgment of the right to wellbeing administrations as basic liberty has additionally been obliged in the second alteration to the 1945 Constitution of the Republic of Indonesia.

It is explicitly expressed in Article 28H section (1) of the 1945 Constitution of the Republic of Indonesia that "Everybody has the privilege to reside in physical and profound thriving, to have a spot to live, and to have a good and sound living climate and to get wellbeing administrations. Not just as common freedom, the right to wellbeing administrations is likewise perceived as resident's protected right. This can be found in Article 34 section 3 of the 1945 Constitution of the Republic of Indonesia (third alteration) which expresses that "The state is liable for giving satisfactory medical care offices and public assistance offices." As right secured by the constitution, the right to wellbeing administrations is exceptionally requested by the public authority.

Everybody has the privilege to approach protected, quality and reasonable wellbeing administrations. This assertion is affirmed in article 5 section (2) of the Health Law. In view of this arrangements, the state addressed by the public authority is obliged to guarantee the accessibility of admittance to protected, quality and reasonable wellbeing administrations for all Indonesian residents to work on friendly government assistance. Government gives offices and foundation in the wellbeing area. This is likewise joined by the accessibility of lawful instruments identified with the arrangement of wellbeing administrations. The accessibility of these legitimate instruments intends to give assurance and insurance to each resident who devours wellbeing administrations given by specialists and clinics.

A few lawful instruments identified with wellbeing administrations that have been set up by the public authority of Indonesia incorporate Law of The Republic of Indonesia Number 29 of 2004 concerning Medical Practice, Law of the Republic of Indonesia Number 36 of 2009 concerning Health and Law of the Republic of Indonesia Number 44 of 2009 concerning Hospitals. As to wellbeing administrations including emergency clinics, specialists and patients, these lawful instruments have been managed by different legitimate instruments. To 
uphold the discipline of specialists and dental specialists in the execution of clinical practice, through Law Number 29 of 2004 concerning Medical Practice Chapter VIII, Indonesian Medical Disciplinary Board (IMDB) was shaped.

As per article 66 of the Medical Practice Law and article 3 of the Indonesian Medical Council Regulation Number 3 of 2011, to uphold the expert discipline of specialists and dental specialists, the Indonesian Medical Disciplinary Board (IMDB) has the obligation to get grievances, look at, and choose instances of supposed infringement proficient discipline of specialists and dental specialists. The grumblings submitted can emerge out of people or organizations who know about supposed infringement of the discipline of specialists and dental specialists in doing clinical practice, or who feel that their advantages have been hurt by the activities of the specialists and dental specialists in doing clinical practices.

Article 1 Number 14 of the Medical Practice Law communicates that the IMDB is an association supported to choose if there have been messes up made by trained professionals and dental experts in the utilization of clinical and dental disciplines and to compel sanctions. Besides, another task of the IMDB is to encourage rules and strategies for managing cases of encroachment of the discipline of trained professionals and dental subject matter experts.

What has been clearly and unequivocally regulated is regarding the duties and responsibilities of the IMDB. The lack of regulation of the IMDB's obligations in the legislation causes gaps in the working procedures of the IMDB which in turn can become a weakness of this state institution.

\subsection{Problem Statement}

In light of the above foundation, a few issues can be distinguished:

1. How is IMDB's obligation in resolving complaints about patient losses in order to optimize IMDB's duties and functions?

2. What is the legal position of the IMDB's decision in the context of enforcing medical professional disciplinary sanctions on doctors and dentists who violate professional discipline?

\subsection{Literature Review}

Article 55 passage 2 of Law Number 29 of 2004 notice that the Indonesian Medical Disciplinary Board is an independent foundation from the Indonesian Medical Council (IMC) and in section 3 it is expressed that the IMDB in doing its obligations is autonomous and capable to the IMC. IMDB in completing its obligations and specialists cannot be affected by anybody. IMDB plays a significant part in authorizing the expert discipline of specialists and dental specialists in Indonesia. The authorization of discipline for specialists and dental specialists completed by IMDB means to shield people in general from activities taken by uncouth specialists or dental specialists and work on the nature of wellbeing administrations, keeping up with the honor of the clinical and dental calling.

Discipline authorization is a demonstration of upholding rules or arrangements for the utilization of science in the execution of clinical practice that should be complied and followed by specialists and dental specialists. Discipline requirement did by the IMBD depends on articles 55-70 of the Medical Practice Law. More low-down blueprints with respect to show prerequisite by the IMDB are contained in the Indonesian Medical Council Regulation Number 15/KKI/PER/VIII/2006 concerning Guidelines for Enforcement of Medical Professional Discipline of Doctors and Dentists, which was in this way superseded by 
Indonesian Medical Council Regulation Number 4 of 2011 concerning Professional Discipline of Doctors and Dentists.

In the event of an alleged violation of professional discipline, the IMDB will receive a report, examine and decide on the alleged violation. The decisions issued by the IMDB are final, and have permanent force, and binding on Indonesian Medical Council and relevant district health offices).[1] The final and legally binding nature of the IMDB decision means that there is no legal action against the IMDB decision. Discipline violations are violations of rules or regulations in the application of medical or dental disciplines, for example incompetence, not in accordance with medical service standards, disgraceful behavior that damages the dignity and honor of the profession.[2] Every medical action that violates the legal provisions in the legislation that causes losses related to the medical profession is included in the violation of medical discipline. Violation of medical discipline does not necessarily violate legal provisions. Constitutional Court Decision Number14/PUU-XII/2014 states that medical discipline is a filter in qualifying the actions of doctors who commit criminal offenses and cause civil harm.

It is explained in article 5 letter I of the Medical Council regulation Number 3 of 2011, that one of the powers possessed by the IMDB is to implement the decisions of the IMDB as the IMDB authority. However, in its implementation, the IMDB cannot implement its decision which contains the imposition of sanctions on doctors or dentists who are declared to have violated the professional discipline of doctors and dentists. The decision of the IMDB containing the imposition of such sanctions must be reported to the Indonesian Medical Council (IMC) to obtain an implementation determination.

There are several changes regarding the issuance period for the determination of the implementation of the IMDB decision by the IMC. In the regulation of the Indonesian Medical Council Number 16/KKI/PER/VIII/2006 article 37 paragraph 2, it is expressed that the execution of the IMDB choice concerning the Sanction of Revocation of the Registration Certificate as alluded to in section 1 will be done no later than 30 days from the date the IMDB choice is gotten by the Indonesian Medical Council. In the following arrangement in the Regulation of The Indonesian Medical Council Number 20 of 2014 article 64 section 1, it is expressed that the IMC will decide the IMC choice in regards to the execution of the IMDB choice inside a limit of 7 working days after the receipt of IMDB choice. There is no arrangement that specifies that IMC can suspend IMDB's choice in regards to the burden of assents for disciplinary infringement.

Based on article 7 paragraph 1 of the Regulation of the Indonesian Medical Council Number 1 of 2011 and article 52 paragraph 1 of the Regulation of the Indonesian Medical Council Number 20 of 2014 it is stated that in the case of imposing disciplinary sanctions in the form of recommendations for revocation of the doctor's registration certificate, the implementation of these sanctions carried out by Indonesian Medical Council (IMC). Further on, the authority of IMC has been confirmed by article 55 paragraph 1 of the Indonesian Medical Council Regulation Number 20 of 2014, it is stated that the IMC is the institution authorized to revoke the doctor's registration certificate in the case violated medical discipline. IMC is executors' disciplinary sanctions that have been set by the IMDB previously. This situation is not in accordance with what is stated in article 55 paragraph 2 of the Medical Practice Law jo. Article 43 of the Regulation of the Indonesian Medical Council Number 3 of 2011. In this provision, it is stated that the IMDB is an autonomous institution from IMC which is independent in carrying out its duties. But in reality IMDB cannot implement the disciplinary sanctions given to doctors or dentists who have violated the 
discipline of doctors and dentists. The disciplinary sanctions set by the IMDB still require an implementation determination from the IMC.

The decision of the IMDB containing the imposition of disciplinary sanctions especially in the form of revocation of the registration certificate of doctor or dentist who violates professional discipline must be reported to IMC to obtain a determination of the implementation of the disciplinary sanction. The role of the IMC in this context is as the executor of the disciplinary sanctions set by the IMDB. This is because the act of revoking registration certificate of doctors and dentists is one of the powers possessed by IMC. In both the Medical Practice Law and the Indonesian Medical Council Regulations, there is no provision that states that IMC has the right to suspend or even cancel the disciplinary sanctions that have been set by the IMDB. Article 52 paragraph 1 jo. Article 64 paragraph 1 of the Regulation of the Indonesian Medical Council Number 20 of 2014 expressly requires Indonesian Medical Council to issue a determination on the implementation of disciplinary sanctions within 7 days. The defendant has the right to file an objection to the disciplinary sanctions given by IMDB in accordance with the article 31 paragraph 2 of the Regulation of the Indonesian Medical Council Number 6/KKI/PER/VIII/2006 which was later amended by article 55 paragraph 1 of the Regulation of the Indonesian Medical Council Number 20 of 2014.

In the provisions of article 7 paragraph 1 letter $\mathrm{c}$ of the Regulation of the Indonesian Medical Council Number 1 of 2011 and article 52 paragraph 1 of the Guideline of the Indonesian Medical Council Number 20 of 2014, it is very clear that IMC is the authorized institution to issue registration certificate for doctors and dentists, as well as revoking the registration certificate in the event that doctors and dentists are subject to disciplinary sanctions by the IMDB. Indonesian Medical Council Regulation Number 1 of 2011 article 7 paragraph 1 letter c, IMC has the authority to issue and revoke registration certificate for doctors and dentists. Indonesian Medical Council Regulation Number 3 of 2011 article 5 letter I states that IMDB has the authority to implement IMDB decisions. Indonesian Medical Council Regulation Number 20 Year 2015 article 52 paragraph (1) mention if the defendant is subject to disciplinary sanctions in the form of a recommendation for the revocation of the registration certificate in accordance with article 51, IMC revokes the defendant's registration certificate.

There is a discrepancy between the three legal provisions. In article 5 letter $\mathrm{i}$ of the Indonesian Medical Council Regulation Number 3 of 2011 it is stated that IMDB has the authority to carry out IMDB decisions according to the authority of the IMDB, but in two other rules, Article 7 paragraph 1 of the Regulation of the Indonesian Medical Council Number 1 of 2011 and article 52 paragraph 1 Indonesian Medical Council Regulation Number 20 of 2014 it is stated that in the case of imposing disciplinary sanctions in the form of recommendations for the revocation of registration certificate imposed on doctors, the implementation of these sanctions is carried out by Indonesian Medical Council.

As indicated by Nasser, a specialist in wellbeing law, clinical debates are questions that happen between patients or their families and specialists/wellbeing laborers or among patients and medical clinics/wellbeing offices with respect to issues identified with administration, therapy and patient consideration.[3] What is regularly questioned is the final product of wellbeing administrations paying little mind to the interaction. In Health Law it is perceived that wellbeing laborers or wellbeing specialist co-ops when offering types of assistance are just answerable for the interaction or endeavors made and don't ensure the end-product.

Article 66 of Law Number 29 of 2004 concerning Medical Practices section 1 expresses that any individual who knows or whose interests have been hurt by the activities of a 
specialist or dental specialist in completing clinical practice can submit a composed question to the Chairperson of the Indonesian Medical Disciplinary Board. Likewise, article 66 paragraph 3 of Law Number 29 of 2004 concerning Medical Practice states that a complaint to the IMDB does not eliminate the right to be able to sue in a criminal or civil courts. This article still opens the possibility for the resolution of medical disputes not only in the IMDB but can also be resolved in civil or criminal courts. As a logical consequence of paragraph 1 article 66 of the Medical Practice Law which gives the patient the right to complain about the practice of doctors and dentist at Indonesian Medical disciplinary Board, Indonesian Medical Disciplinary board has given an obligation in resolving complaints of patient losses.

\section{Research Methods}

\subsection{Types of Research}

The sort of exploration in this examination is standardizing juridical exploration, since this exploration was led by looking at library materials and essential information identified with the capacities, obligations and commitments of the Indonesian Medical Disciplinary Board and the settlement of patient objections by the Indonesian Medical Disciplinary Board. Regularizing juridical examination is additionally called doctrinal lawful exploration or library research, which is library research that inspects archives, utilizing different optional information like laws and guidelines, court choices, legitimate speculations and well-qualified conclusions.

\subsection{Research Specifications}

This research is descriptive analytical and prescriptive analytical, namely describing data obtained from observations, interviews, documents and field notes, then analyzed. In this study, it was investigated using library materials (secondary materials) or library law research.

\subsection{Research Approach}

\section{a) Invitation Law Approach (Statute P Approach)}

The methodology is taken by analyzing all laws and guidelines identified with the Indonesian Medical Disciplinary Board, regardless of whether the laws and guidelines as of now direct the commitments of the Indonesian Medical Disciplinary Board.

\section{b) Limited Empirical Approach}

Approach by interviewing the speaker, the chairman of Indonesian Medical Disciplinary Board, dr. Dody Firmanda, SpA (K), MA, member of MKDKI dr. Johan Akbari, SpS, SH, MARS. Head of KKI Prof.dr. Bambang Supriyanto, SpA (K), member of KKI Prof.dr. Sukman Tulus Putra, SpA (K), Health law expert Dr.dr. Nasser, SpKK, D. Law and the Head of IDI Jakarta Region, dr. Slamet Budiarto, SH. Interviews were also conducted with members of IDI (Indonesian Doctors Association) and PDGI (Indonesian Dentist Association) who had been sentenced by Indonesian Medical Disciplinary Board and who were released by Indonesian Medical Disciplinary Board. 


\section{c) Conceptual Approach}

The reasonable methodology is a sort of approach in lawful examination that gives an insightful perspective of critical thinking in legitimate exploration seen from the parts of the lawful ideas driving it or can even be seen from the characteristics contained in the norming of a rule similar to the thoughts used.

\section{Analysis and Discussion}

Based on the literature, the regulation of Indonesian Medical Disciplinary Board's obligations both in the settlement of complaints about patient losses and in improving the quality of doctor and dentist services has not been exhaustively directed in lawful instruments in different laws and regulations. There is no legal construction that stipulates that Indonesian Medical Disciplinary Board can perform its obligations optimally. The following are some rationales that can be considered in formulating the Indonesian Medical Disciplinary Board's obligations so that it can function optimally both in resolving complaints of patient losses and in enforcing professional discipline. The obligations of the Indonesian Medical Disciplinary Board include:

1. Responsibilities to complainants. Notify the complainants at each stage of handling complaints of public losses

2. The obligation to carry out the purity of medical science. Guarantee that specialists and dental specialists offer clinical types of assistance as indicated by Professional Standards, Medical Service Standards and Standard Operating Procedures.

3. Obligation not to be influenced by other factors such as gifts. Indonesian Medical Disciplinary Board's decision is not influenced by other interests and other factors, does not ask for or accept gifts from other people that affect the way in which decisions are made. IMDB have the highest standards of propriety and accountability, anti-corruption.

4. Fulfillment of obligations in monitoring Indonesian Medical Disciplinary Board decisions

a. Written warning, something that is given to a doctor or dentist as a warning for a violation of discipline in written form.

b. Recommendation for revocation of Registration Certificate or Practice License, registration certificate is a legal document issued by Indonesian Medical Council for doctors and dentists that the person has met the requirements and has been registered with the Indonesian Medical Council. Practice License is a letter given by the district / city health office to doctors and dentists who will practice medicine after fulfilling the requirements.

c. Commitment to go to instruction or preparing in clinical or dental instructive foundations. Specialist or dental specialist who are endorsed are needed to go to schooling or preparing in establishments that give clinical or dental training.

5. The obligation to provide guidance and supervision of medical practice. Develop medical professional disciplinary standards and oversee their implementation. The development of medical professional discipline can be carried out together with the division of medical council development through monitoring and evaluation functions.

6. Uphold professionalism and integrity in carrying out medical practice. The primary reason for specialists and dental specialists to have the option to perform clinical activities on others in the information, innovation, and abilities which are gotten through instruction and 
training. The information possessed must be ceaselessly kept up with and worked on as per the advancement of science and innovation itself.

7. Obligation to monitor and evaluate the sanctioned doctor or dentist. The monitoring time, for example is set for six months. If new violations are found during the monitoring period, the reported party may be subject to further sanctions.

In Indonesian Medical Council Regulation Number 32 of 2015 concerning Procedures for Handling Cases of Alleged Violations of Discipline of Doctors and Dentists article 62 area 2 it is communicated: (1) Indonesian Medical Disciplinary Board choices are choices in the field of expert discipline of specialists and dental specialists (2) Indonesian Medical Disciplinary Board choices as alluded to in passage 1 not a choice concerning the legitimate field with the goal that it can't be deciphered as an infringement or mistake in the lawful field.

In the IMC guideline it is expressed certainly that the IMDB choice can't be utilized as proof in deciding the presence of carelessness in clinical activities completed by specialists. The IMC guideline expresses that the MKDKI's choice doesn't include the lawful field so it can't be deciphered as an infringement or mistake in the lawful field. In case it is identified with the types of disciplinary infringement contained in Article 3 section 2 of the IMC Regulation Number 4 of 2011 which has a relationship with the lawful arrangements dispersed in the laws and guidelines, it tends to be seen that there is an error.

Proof is a provision that contains guidelines on procedures justified by law to prove the guilt that has been charged to the defendant. Determining the negligence of a doctor is not easy because the negligence of a doctor is negligence in the field of profession, so judges who do not master this field are not easy to decide in court. Perpetrators of criminal acts can only be sentenced if their actions can be proven by means of evidence according to the law, which is stated in article 184 of the Criminal Procedure Code.

As far as proof dependent on article 184 of the Criminal Procedure Code, the IMDB choice can be utilized as narrative proof. As per Article 187 of the Criminal Procedure Code, a letter that can be evaluated as lawful proof as per the law is a letter committed to on a promise of office or a letter affirmed by a vow. In article 187 letter $b$ it is expressed "A letter made by the arrangements of the enactment or a letter made by an authority with respect to issues that are remembered for the administration for which he is dependable and which is planned to demonstrate something or a circumstance. "The explanation of article 187 letter $b$ of the Criminal Procedure Code states "what is meant by a letter made by an official, including a letter issued by an authorized assembly for that". IMDB decisions are issued by authorized officials or official institutions, where IMDB is an institution established by the state based on article 55 of the Medical Practice Law. The IMDB decision was made through a legal process based on the IMC Regulation as a regulation authorized by the Medical Practice Law article 70. Evidence at the IMDB was carried out by submitting evidence based on article 37 of the IMC Regulation No. 32 of 2015. Based on this, the IMDB decision can be used as letter evidence.

On the other hand, article 62 paragraph 2 of the KKI Regulation Number 32 of 2015 implies that the MKDKI's decision whether it decides a doctor or dentist to violate medical discipline or a doctor or dentist who is not guilty of violating medical discipline cannot be used as evidence, especially for evidence of medical negligence. The KKI regulation is contrary to the Constitutional Court Decision Number 14/PUU-XII/2014 in its legal considerations making medical science, especially the code of ethics and medical discipline as one of the references in conducting investigations, investigations, prosecutions and trial examinations and as a reference in proving the existence of medical negligence. The Constitutional Court's decision states that medical discipline is a filter in qualifying the actions 
of doctors who commit criminal offenses and cause civil harm.[4] The Constitutional Court's decision stated that medical discipline is a scientific standard that must be carried out by doctors to carry out medical actions they do.

Article 2 letter a of the Medical Practice Law states that medical practice must be based on science and technology acquired both in education including continuing education as well as experience and professional ethics. If the medical practice carried out by a doctor or dentist against a patient must be based on science and technology obtained in education and experience as well as professional ethics, then it should be in proving the actions of a doctor or dentist are considered to cause harm to the patient or the doctor is suspected of having committed medical negligence must be based on medical science.

Indonesian Medical Disciplinary Board (IMDB) is the foundation approved to decide if there are blunders of specialists and dental specialists in the use of clinical and dental disciplines. For this situation, MKDKI demonstrates it as far as clinical science. Criminal complaints or civil lawsuits to courts related to doctors or dentists as one of the parties must be synergized with medical discipline as a reference in identifying the actions of doctors or dentists entering the realm of law or not. Law enforcement officials in interpreting legal regulations governing the actions of doctors or dentists use medical discipline as the main reference. The Constitutional Court makes medical discipline as the main reference for conducting investigations, investigations, prosecutions and trial examinations. There are several forms of disciplinary violations that are regulated in the legal provisions which are spread in the Indonesian Medical Council Regulation Number 4 of 2011.

Article 29 of Law Number 36 of 2009 concerning wellbeing specifies that, "if a wellbeing specialist is associated with carelessness in completing his calling, the carelessness should be settled first through intervention." According to Hermien Hadiati Koeswadji, the provisions of generally accepted legal regulations, whether in civil law, criminal law or administrative law, cannot be applied to cases where one of the parties is a doctor as a medical worker.[5] The element of negligence in the medical profession in the form of negligence in criminal law is gross negligence (culpa lata) not minor negligence (culpa levis). Negligence is not a violation of the law if it does not harm or injure another person and that person can accept it. In medical negligence, the main concern is the "cause" of the resulting consequences, namely negligence in the medical profession.

In Law Number 8 of 1981 concerning the Criminal Procedure Code, one of the lawful proofs depends on article 184 passage 1 letter c of the Criminal Procedure Code is letter proof: "A letter is one that contains perusing signs expected to spill one's guts or to pass on somebody's contemplations and use as proof. Everything that does not contain reading marks, or even though it contains reading marks but does not contain ideas, is not included in the meaning of written evidence or letters." Based on article 184 of the Criminal Procedure Code, it can be interpreted that the IMDB decision can be used as documentary evidence. According to Article 187 of the Criminal Procedure Code, a letter that can be assessed as valid evidence according to the law is a letter made on an oath of office or a letter issued by oath. Article 187 letter $b$ of the Criminal Procedure Code states: A letter made according to laws and regulations or an official regarding matters that are included in the management for which they are responsible and are intended to prove a matter or condition.

IMDB decisions is letters made according to the legislation because they are made based on the regulations which are regulations that are authorized attribution by the medical practice law. The IMDB decision also proves whether or not there is a violation of medical discipline. Based on article 187 letter b of the Criminal Procedure Code, the IMDB decision can be used as documentary evidence because the elements of the type of letter have been 
fulfilled. The IMDB decision as a decision based on a complaint or initial evidence submitted by the complainant can be used as initial evidence in the complaint process at the court level, especially criminal. This is because the IMDB decision contains preliminary facts resulting from the investigation and proof process at the IMDB. The IMDB decision has gone through a series of processes and is the result of a process of handling professional discipline.

Hary Sasangka and Lily Rosita expressed that what is implied by proof is all that has to do with a demonstration, which implies that proof can be utilized as proof to bring the adjudicator's conviction up in the reality of a criminal demonstration that has been carried out by the litigant.[6] The IMDB choice has satisfied the components of narrative proof as one of the proof perceived in the Criminal Procedure Law evidentiary interaction on the grounds that the MKDKI choice contains the accompanying issues: gave by an approved authority/official organization, helped out through a legitimate cycle dependent on the law, the cycle did inside and out on the grounds that it is done by an independent establishment that has the position to get, analyze and choose instances of infringement of expert discipline.

The appointed authority delivers a condemning choice if the demonstration accused of the litigant is demonstrated legitimate dependent on at least two bits of proof, as per article 183 of the Criminal Procedure Code. The arrangements for proof in Article 183 of the Criminal Procedure Code are controlled in Article 184 passage 1 of the Criminal Procedure Code, specifically witness explanations, master proclamations, letters, guidelines and articulations of the litigant.

With the authorization of Article 66 passage (3) of Law Number 29 of 2004 which states "Grumblings as alluded to in sections (1) and (2) don't dispose of the right of everybody to report speculated criminal demonstrations to the skillful specialists or case common harms to the specialists court," this article brings about an expansive translation. This paragraph gives rise to the interpretation that all doctor's actions have the potential to be categorized as criminal acts and can be brought into the realm of law. What is meant by criminal acts in that article is only the actions of doctors that contain elements of negligence and intentional. Medical actions that can be brought into the realm of law are only those that contain intentional (dolus) or gross negligence (culpa lata). Actions beyond that are the competence of the IMDB for violations of the professional discipline of doctors and dentists or the competence of the Indonesian Medical Ethics Board for violations of medical ethics.

As per the arrangements of Article 55 section (2) and passage (3) of the Medical Practice Law, the IMDB is an independent establishment from the Indonesian Medical Council (IMC) and in doing its obligations is autonomous. The assessment of grumblings at IMDB includes different specialists identified with instances of supposed infringement of clinical discipline that are whined of, Article 29 of Law Number 36 of 2009 concerning Health specifies that "if wellbeing laborers are associated with carelessness in doing their calling, the carelessness should be settled first through intercession." Article 50 of the Medical Practice Law expresses those specialists and dental specialists are qualified for lawful assurance as long as they do their obligations as per proficient norms, standard working systems and satisfy the interests of patients.

With the entry into force of Article 66 paragraph (3), it has created legal uncertainty. Legal uncertainty arises when a person has been examined and found not guilty of violating the discipline by the Indonesian Medical Disciplinary Honorary Council, but is found guilty in criminal or civil courts. Another legal uncertainty occurs because it is possible for the public to ignore the process at IMDB by directly complaining about a doctor through a criminal or civil process. Through Article 66 paragraph (3), complaints against doctors and dentists do not have to go through the IMDB, so that complaints outside the IMDB are possible. Article 55 
paragraph (1) of the Medical Practice Law states "to enforce the discipline of doctors and dentists in the implementation of medical practice, the Indonesian Medical Discipline Honorary Council or IMDB for short is formed." There is no provision that any reporting of alleged criminal acts to the authorities or claims for civil damages to the court must first be examined whether there is a violation of the professional discipline of the doctor or dentist concerned by the IMDB. It may happen that a doctor or dentist is found criminally guilty or has caused civil harm by the court without first going through the process of examining the professional discipline of doctors and dentists by the IMDB. It may also happen that a doctor or dentist who is found not guilty of having committed a disciplinary violation by the IMDB is found guilty of committing a crime or has committed an unlawful act that causes civil harm by a district court.

Article 60 passage (1) of the Regulation of the Indonesian Medical Council Number 32 of 2015 concerning Procedures for Handling Cases of Alleged Violations of Discipline of Doctors and Dentists expresses "The IMDB choice is conclusive and has extremely durable power and its extracts are perused transparently in the meeting perusing the choice." Although the IMDB's choice is supposed to be conclusive and restricting, in its execution there are endeavors to take other legitimate cures through a claim to the State Administrative Court. The State Administrative Court decision which annuls the IMDB decision and the IMC decision has occurred in the case of dr. Iqbal, SpS at the Pekanbaru Administrative Court which occurred in August 2018. Another example is the Jakarta State Administrative Court Decision Number 84/G/2011/PTUN-JKT and in the case of Prof. Dr. dr. Eka Julianta Wahyoe Pramono, SpBS, Supreme Court Decision Number 298K/TUN/2012 on August 29, 2012.

The documenting of a claim against the choice letter of the Indonesian Medical Disciplinary Board (IMDB) to the State Administrative Court depends with the understanding that IMDB is a state managerial body or official as expressed in Article 1 number 8 of Law Number 51 of 2009 concerning the Second Amendment to Law Number 5 of 1986 concerning the State Administrative Court which states: "State authoritative bodies or authorities are bodies or authorities who complete government issues dependent on pertinent laws and guidelines." Article 1 number 11 expresses: "A claim is an application that contains a case against a state regulatory body or official and is submitted to the court to acquire a choice". Regarding this arrangement, the IMDB is remembered for the class of state managerial body or official, in light of the fact that the IMDB was shaped dependent on the command of Law Number 29 of 2004 concerning Medical Practices to authorize the discipline of the calling of specialists and dental specialists in Indonesia. Article 1 passage 8 Law Number 51 of 2009 states that a state authoritative choice that can be utilized as an object of question in a state managerial court should be a composed assurance given by a state regulatory organization or official containing lawful activities for state organization dependent on appropriate laws and guidelines, which are concrete, individual and last, which have legitimate ramifications for an individual or common lawful element.

Article 87 of Law Number 30 of 2014 concerning Government Administration expresses that State Administrative Decisions should be deciphered as: composed specifications which additionally incorporate real actions, decisions of State Administration Bodies as well as Officials in the chief, authoritative, legal, and other state managers, in light of legal arrangements and general standards of good administration, are last from a more extensive perspective, choices that can possibly cause legitimate outcomes, or potentially or choices that apply to residents. This underlies the view that the IMDB choice has met the measures as a state authoritative choice that can be utilized as an object of question. This article gives a development of the extent of state regulatory choices. Because of the development of the 
extent of the state regulatory choices as specified in Article 87 of Law Number 30 of 2004, many adjudicators of the state authoritative court have acknowledged the claim against the IMDB choice letter which contains disciplinary approvals for specialists and dental specialists who are demonstrated to have disregarded proficient discipline.

Then again, article 62 of the Indonesian Medical Council Regulation Number 32 of 2015 concerning Procedures for Enforcement of Cases of Alleged Violations of Discipline of Doctors and Dentists communicates that the IMDB decision is a decision in the field of clinical master discipline and is certainly not a decision concerning the legal field so it can't be translated that it has encroachment or goof in the field of law. The requirement of the expert discipline of specialists and dental specialists ought to be isolated from the legitimate field, in light of the fact that the implementation of this discipline is planned to secure people in general, keep up with and work on the nature of wellbeing administrations, and keep up with the honor of the calling of specialists and dental specialists.

The choice of the IMDB which specifies the inconvenience of approvals on specialists and dental specialists who are demonstrated to have abused proficient discipline will be sent to the Indonesian Medical Council (IMC) for execution. The IMC will carry out the approvals as per Article 66 passage (2) of the Indonesian Medical Council Regulation Number 32 of 2015 concerning Procedures for Handling Cases of Alleged Violations of Discipline of Doctors and Dentists which expresses that the execution of the denial of the Registration Certificate is completed by the IMC. Article 2 of Law Number 5 of 1986 jo. Law Number 9 of 2004 concerning State Administrative Courts expresses that state regulatory choices that actually require endorsement from unrivaled organizations are not state authoritative choices that can be submitted as objects of debate in state managerial courts.

Indonesian Administrative Court is a place to examine violations of the provisions of State Administrative Law, where violations of professional discipline are not included in the area of mere administrative norm violations but are more of a violation of professional discipline norms. So, it is clear that the laws and regulations that are violated and then tried in the Administrative Court are administrative violations, while the violation of medical discipline decided by the IMDB is the realm of professional discipline so that it cannot be canceled by the Indonesian administrative court which incidentally only hears violations of the State Administration. Article 67 of Law Number 29 of 2004 concerning Medical Practice states that the Indonesian Medical Disciplinary Board (IMDB) examines and makes decisions on complaints related to the discipline of doctors and dentists. Enforcement of discipline is not a matter of state administration.

Medical failure is not always the result of the actions of a doctor or dentist, but may be due to the medical risks inherent in every medical procedure. Proving the existence of allegations of medical negligence by doctors is very difficult to do. The provisions of generally accepted legal regulations, both in civil law, criminal law and criminal procedural law cannot be applied immediately to cases in which one of the parties is a doctor as a medical worker, this is because in proving the alleged negligence of medical action must also use an approach field of medical science.

\section{Conclusion}

a. The Indonesian Medical Disciplinary Board's (IMDB) obligation in resolving complaints of patient losses in the context of optimizing the duties and functions of the IMDB has not been comprehensively regulated in the existing regulatory instruments. The absence of 
regulation regarding IMDB's obligations in the available regulations has caused, among other things, the independence of the IMDB to be mentioned a lot in the medical profession. This also has the potential to make IMDB act arbitrarily and as if it were a super body. In addition, in order to optimize its duties in resolving patient complaints, IMDB is often confused and acts beyond its authority because it is not exposed to information about the balance of rights and obligations.

b. The legal position of the IMDB decision in the context of enforcing professional disciplinary sanctions on doctors and dentists has not been clearly and unambiguously described in relation to legal norms, so there are still lawsuits that go to the Criminal, Civil or Administrative Court that use the IMDB decision so that it can be said that the IMDB decision is still leaving the problem of legal norms due to the unclear explanation of IMDB's obligations.

\section{References}

[1] Putusan Mahkamah Agung Republik Indonesia Nomor 56/G/2014/PTUN-JKT Tanggal 12 Agustus 2014

[2] Wijaya, I Komang Gede Oka. "Putusan Majelis Kehormatan Disiplin Kedokteran Indonesia sebagai alat bukti dalam Hukum Acara Pidana.” Yuridika 32(1):37, JanuariApril (2017)

[3] Lawuad. "M.Nasser Beri Wawasan Sengketa Medik". Universitas Ahmad Dahlan Perguruan Tinggi Muhammadiyah, Januari 13th, (2018) https://law.uad.ac.id/mnasser-beri-wawasan-sengketa-medik/ Accessed on Desember 10, 2020

[4] Putusan Mahkamah Konstitusi Nomor 14/PUU-XII/2014 dalam pertimbangan hukumnya menjadikan ilmu kedokteran, khususnya kode etik dan disiplin kedokteran sebagai salah satu rujukan dalam melakukan penyelidikan, penyidikan, penuntutan serta pemeriksaan sidang.

[5] Hermien Hadiati Koerwadji, Some legal and Medical Issues, Bandung: Citra Aditya Bakti, 2012

[6] Hari Sasangka dan Lily Rosita, The Law of Evidence in Criminal Cases, Mandar Maju, 2003

[7] Australian General Medical Council, Code of Conduct, (2020)

[8] Breen, Kerry J. Good Medical Practice, Professionalism, Ethics and Law. Cambridge University Press, (2019)

[9] Chandrawila, Wila, Medical Law, Jakarta: CV Mandar Maju, (2007)

[10] Chazawi. Medical Malpractice. Malang: Bayu Media Publishing, (2007)

[11] Creswell, John W. Research Design. Third edition, California: Thousand Oaks, (2009)

[12] Dollar. Legal Liability of Doctors in Malpractice. FH Untar, Jakarta, April (2015)

[13] Donald. Introductory Address on The General Medical Council, Its Powers and Its Works: Delivered at the University on October $2^{\text {nd }}$, 1906. Forgotten Books, Classic Reprints, (1995)

[14] Federation of State Medical Boards, US, Annual reports, (2021)

[15] General Medical Council Great Britain. Minutes of the General Council of The General Medical Council of the Executive Committee and of the Branch Councils. Volumes I-X (1858-1873), p 1-287, Great Britain: Leopold Classic library, (2005)

[16] Irvine, Donald. The Doctor's Tale, Professionalism and Public Trust, CRC Press, Taylor and Francis Group, (2003) 
[17] Jayasurya, DC. Health Law (International and Regional Perspective). New Delhi: Anand Publication PUT Ltd, (1997)

[18] Komalawati, Veronica. Law and Ethics in Doctor's Practice. Jakarta: Pustaka Sinar Harapan, (1989)

[19] Medical Council of New Zealand, New Zealand, (2020)

[20] Merdias. Set of Rules About Indonesian Medical Disciplinary Board. Jakarta: Konsil Kedokteran Indonesia, (2006)

[21] MKDKI. Penegakan Disiplin Kedokteran Indonesia oleh MKDKI. Jakarta: MKDKI, (2013)

[22] Nasution, Bahder Johan. Doctor's liability health law. Jakarta, PT Rineke Cipta, (2005)

[23] Ohoiwutun, Y.A Triana. Medical Law Anthology. Bayumedia Publishing, (2009).

[24] Public Heath Medicine General Medical Council. Regulating Doctors Ensuring Good Medical Practice. UK: Public health Medicine General Medical Council Books, (2000)

[25] Rianto. Medical malpractice Law. Yogyakarta : Total Media, (2011)

[26] Sjahdeini, Sutan Remy. Health Law regarding Medical Malpractice. Bogor: IPB Press, (2020)

[27] Smith, Russel. Medical Discipline: The Professional Conduct Jurisdiction of the General Medical Council. 1858-1990, Oxford: Clarendon Press, (1994)

[28] Stephen. Australian Medical Council, Good Medical Practice, Professionalism, Ethics and Law. AMC (2019)

[29] Wahjoepramono, Eka Julianta. Legal Consequences in the Medical Profession. Bandung: Karya Putra Darwati, (2012)

[30] Yunanto, Ari. Medical Malpractice Criminal Law. Yogyakarta: Andi, (2010)

[31] Andryawan. Kedudukan Majelis Kehormatan Disiplin Kedokteran Indonesia (MKDKI) dan Konsil Kedokteran Indonesia (KKI) dalam Penegakan Disiplin Kedokteran di Indonesia. Studi Putusan Mahkamah Agung RI Nomor: 298K/TUN/2012,

[32] Aprilianto, Sapta. Peran Majelis Kehormatan Disiplin Kedokteran Indonesia (MKDKI) Terhadap Dugaan Kelalaian Medis Dokter. Yuridika Vol.30, No.3, Journal of Health Care Law and Policy, 13 (2),285-323 (2015)

[33] Birkeland. Legal System's responses to Medical Malpractice. Internal Medicine Journal,Vol. 46 No.9, (2016)

[34] Chandra. Progress in medicine: Compensation and Medical Negligence in India. Does The System need a quick fix or an overhaul?. Annals of Indian Academy of Neurology, Vo. 19, Suppl 1, (2016)

[35] Diana. Tanggung Jawab Dokter Dalam Terjadinya Malpraktik Medik ditinjau Dari Hukum Administrasi. Badamai Law Journal Vol.2 Issues 2, September (2017)

[36] Firmanda, Dody. Majelis kehormatan Disiplin Kedokteran Indonesia dalam Dugaan Pelanggaran Disiplin Kedokteran. Fatmawati Hospital Journal February (2018)

[37] Hendra, Wellem. Provisions of Indonesian Medical Discipline Sanctions to Protect The Rights of Patient be Reviewed From The Principle of the Establishment of Legislation. Soepra Jurnal Hukum Kesehatan Vol.4 No.2 Desember (2018)

[38] Heryanto. Malpraktik Dokter dalam perspektif Hukum. Jurnal Dinamika Hukum Vol.10 No.2, Mei (2010)

[39] Hiyama. The number of criminal Prosecutions Against Physicians due to Medical Negligence is on the rise in Japan. The American Journal of Emergency Medicine, Vol.26 No.1, (2008)

[40] Jacobi, John V. Competition Law's Role in Health Care Quality. 11 Annals Health L 45, (2002) 
[41] Kusuma, Nila. Law and Medical Disciplinary Sanctions: Enhancing Medical Parctice and Health Quality in Indonesia. Journal of Legal, Ethical and Regulatory Issues: Vol.21, Issue 4, (2018)

[42] Lalu. The Discourse of medical Malpractice Punishment in Criminology Perspective. Jurnal Hukum Kesehatan Vol.6 No.2, Desember 2020

[43] Lee. The Effects of Criminal Punishment on Medical Malpractices in the Medical Environment. International Journal of Environmental research and Public Health, 16 (4), 2019

[44] Leflar. The Regulation of medical Malpractice in Japan. Clinical Orthopedics and Related Research, 467 (2), (2009)

[45] Michel. Perlindungan Hukum terhadap Dokter dalam memberikan Pelayanan Medis. Lex et Societatis, 2(8), (2014)

[46] N., Khairunnisa. Tinjauan Yuridis Tugas dan Wewenang Majelis Kehormatan Disiplin Kedokteran Indonesia. Diponegoro Law Journal, Vol.6 No.2, (2017)

[47] Nagata. Punishment of medical Malpractice in Japan. Internal Medicine Journal, 46 (1), (2016)

[48] Nayla. The Role of Indonesian Medical Disciplinary Board's Verdict On Medical Disciplinary Violation in Medical Disputes Settlement. Jurnal Dinamika Hukum Faculty Of Law Universitas Jenderal Soedirman Vol.17 No.1, (2017)

[49] Nuryanto. Model Perlindungan Hukum Profesi Dokter. Jurisprudence Vol.1 No.1, Juli (2012)

[50] Panggabean. Penanganan Kasus Malpraktek yang Responsif dalam Sistem Peradilan Indonesia, Law Review UPH Vol.13 No.3, (2014)

[51] Patria. The Role of Indonesian Honorary Council of Medical Discipline in Upholding Indonesian Medical Code of Ethics. Advances in Social Science, Education and Humanities Research, Vol. 358, (2019)

[52] Ridwan. Criminal Legal Accountability on Medical Privacy Violations, J Heath Policy and Management, 4 (1)

[53] Roland, Julius. Akibat Hukum Malpraktik Yang Dilakukan Oleh Tenaga Medis. Jurnal Interpretasi Hukum Vol.1 No.1, Agustus (2020)

[54] Rompis. Perlindungan Hukum terhadap Dokter Yang Diduga Malpraktek, Lex Crimen Vol.6 No.4, (2017)

[55] Santoso, Arif Dian. Penyelesaian Sengketa Medik Melalui Mediasi oleh MKDKI Untuk Dapat Menjamin Keadilan Dalam Hubungan Dokter dan Pasien. Jurnal UNS Vol.7 No.1, (2019)

[56] Satria, Beni. Perlindungan Hukum Terhadap Dokter Atas Dugaan Melakukan Tindak Pidana Medik Dihubungkan Dengan Ajaran Sifat Melawan Hukum Materiil. Jurnal Ilmiah Abdi Ilmu Vol.12 No.1, (2019)

[57] Sawicki, Nadia N. Character, Competence and the Principles of Medical Discipline. Journal of Health Care Law and Policy, Volume 13, Issue 2, (2010)

[58] Setiadi, Wicipto. Sanksi Administratif Sebagai Salah satu Instrumen Penegakan Hukum Dalam Peraturan Perundang Undangan. Journal Legislasi Indonesia Vol.6 No.4 Desember (2009)

[59] Setyo. Perlindungan Hukum Profesi Dokter dalam Penyelesaian Sengketa Medis. Jurnal Pembaharuan Hukum, Volume IV No.1 Januari - April (2017)

[60] Timothy. Complaints and Professional Discipline, A look at medical Licensure boards, Heath Matrix, 3 (1) 
[61] Venny. Pertanggungjawaban Perdata Dokter Dalam Kasus Malpraktek Medis. Lex JurnalVol.12 No.2, (2015)

[62] Vera, Iip. The Legal Consequences of Informed Consent for Doctors and Patients in Therapeutic Agreements. Aijha Vo.3 No. 6, June (2020)

[63] Violato. Errors and Patient Safety. Canadian Medical Education Journal, 4 (1),1-6, (2013)

[64] Yackee. Private Confict and Policy Passage: Interest-Group Conflict and State Medical Malpractice Reform. The Policy Studies Journal,37,213-231, (2009)

[65] Yasir, Ahmad. Disparitas Putusan Malpraktek Kedokteran Studi Putusan Mahkamah Agung No. 365K/PID/2012, Jurnal Ilmiah Kohesi Vol.4 No.4, (2020)

[66] Yussy. Legal Relations Between Doctors and Patients and The Accountability of Doctors in organizing Health Services. Jurnal Cita Hukum Vol.6 No.1, (2018)

[67] 1945 Constitution of the Republic of Indonesia.

[68] Government Regulation Number 32 of 1996 concerning Health Workers.

[69] Indonesian Constitution Number 5 of 1986 concerning Administrative Court

[70] Indonesian Constitution Number 23 of 1992 concerning Health

[71] Minister of Health Regulation No. 150/MENKES/PER/I/2011 concerning MKDKI Membership

[72] Law Number 8 of 1981 concerning Criminal Procedure Code (KUHAP)

[73] Law Number 9 of 2004 concerning Amendments to Law Number 5 of 1986

[74] Law Number 29 of 2004 concerning Medical Practice

[75] Law Number 36 of 2009 concerning Health

[76] Law Number 44 of 2009 concerning Hospitals

[77] Law Number 48 of 2009 concerning Judicial Power

[78] Law Number 51 of 2009 concerning the Second Amendment to Law Number 5 of 1986 concerning State Administrative Court

[79] Law Number 12 of 2011 concerning the Establishment of Invitation Regulations

[80] Indonesian Medical Council Regulation No. 15/KKI/PER/VIII/2006 concerning Organization and Work Procedures of MKDKI and MKDKI at the Provincial Level

[81] Indonesian Medical Council Regulation Number 15/KKI/PER/VIII/2006 concerning the Organization and Work Procedures of MKDKI and MKDKI at the Provincial Level.

[82] Indonesian Medical Council Regulation Number 16/KKI/PER/VIII/2006 concerning Procedures for Handling Cases of Alleged Violations of Discipline of Doctors and Dentists by MKDKI and MKDKI at the Provincial Level.

[83] Indonesian Medical Council Regulation Number 36/KKI/PER/VIII/2007 concerning the Functions, Duties and Work Procedures of the Indonesian Medical Council.

[84] Indonesian Medical Council Regulation Number 48/KKI/PER/XII/2010 concerning Additional Authorities for Doctors and Dentists

[85] Indonesian Medical Council Regulation Number 1 of 2011 concerning Organization and Work Procedure of KKI

[86] Indonesian Medical Council Regulation Number 2 of 2011 concerning Procedures for Handling Cases of Alleged Discipline Violations of Doctors and Dentists

[87] Indonesian Medical Council Regulation Number 3 of 2011 concerning the Organization and Work Procedure of MKDKI and MKDKI at the Provincial Level.

[88] Indonesian Medical Council Regulation Number 4 of 2011 concerning Professional Discipline of Doctors and Dentists. 
[89] Indonesian Medical Council Regulation Number 10 of 2012 concerning Medical Professional Education Standards

[90] Indonesian Medical Council Regulation Number 11 of 2012 concerning Indonesian Doctor Competency Standards.

[91] Indonesian Medical Council Regulation Number 20 of 2014 concerning Procedures for Handling Cases of Alleged Discipline Violations of Doctors and Dentists.

[92] Indonesian Medical Council Decision Number 17/KKI/KEP/VIII/2006 concerning Guidelines for Enforcement of Medical Professional Disciplines

[93] Indonesian Medical Council Decision Number 18/KKI/KEP/2006 concerning the Book of Good Medical Practice in Indonesia

[94] Indonesian Medical Council Decision Number 20/KKI/KEP/IX/2006 concerning Ratification of Medical Education Standards

[95] Indonesian Medical Council Decision Number 21A/KKI/KEP/IX/2006 concerning Ratification of Doctor Competency Standards.

[96] Regulation of the Minister of Health of the Republic of Indonesia Number 290/MENKES/PER/III/2008 concerning Approval of Medical Actions.

[97] Decision of the Supreme Court of the Republic of Indonesia Number: 61K/TUN/1999

[98] Decision of the Supreme Court of the Republic of Indonesia Number 210K/TUN/2011

[99] Decision of the Supreme Court of the Republic of Indonesia Number 298K/TUN/2012

[100] Decision of the DKI Jakarta State Administrative High Court Number 242/B/2011/PT.TUN.JKT.

[101] Jakarta State Administrative Court Decision Number 84G/2011/PTUN-JKT

[102] Jakarta State Administrative Court Decision Number 198/G/2013/PTUN-JKT.

[103] North Jakarta District Court Decision Number 237/PDT.G/2009/PN.JKT.UT 